\title{
ЗАБЕЗПЕЧЕННЯ НАДІЙНОСТІ РОБОТИ АЛМАЗОВМІСНОГО ІНСТРУМЕНТУ, ОТРИМАНОГО ЛАЗЕРНИМ ТЕРМОДЕФОРМАЦЙНИМ СПІКАННЯМ, ПРИ ОБРОБЩ АРМОВАНИХ ВУГЛЕПЛАСТИКІВ
}

\author{
О. Ф. Саленко, В. Т. Щетинін, В. І. Глухова, Є. Є.Лашко
}

Кременчуцький національний університет імені Михайла Остроградського

вул. Першотравнева, 20, м. Кременчук, 39600, Україна. E-mail: salenko2006@ukr.net

Л. Ф. Головко, А. О. Саленко

Національний технічний університет України «Київський політехнічний інститут імені Ігоря Сікорського» просп. Перемоги, 37, м. Київ, 03056, Україна.

Мохамед Р. Ф. Будар

просп. Університетський, 8, м. Кропивницький, 25006, Україна.

Розглянуто питання забезпечення надійності роботи алмазовмісного інструменту, отриманого лазерним термодеформаційним спіканням. Зазначений інструмент використовується для обробки вуглепластиків, вуглець-вуглецевих матеріалів. При цьому низька оброблюваність, підвищені температури в зоні різання та ряд механіко-хімічних явищ веде до втрати різальної здатності інструменту. Запропоновано ймовірнісні моделі настання параметричної відмови роботи алмазовмісного інструменту, показана його деградація у процесі експлуатації. Показано, що лазерне термодеформаційне спікання забезпечує більшу міцність зерна у сполучнику, а також більший виліт зерна із поверхні, що дозволяє поліпшити умови роботи інструменту. Приведено основи технології лазерного спікання, запропоновано новий дозувальний пристрій кільцевого типу для введення алмазів. Також зроблено висновок, що лазерне спікання дозволяє більш ефективно очищувати і регенерувати алмазовмісний шар інструменту.

Ключові слова: вуглепластик, алмазовмісний інструмент, лазерно-деформаційне спікання.

\section{ОБЕСПЕЧЕНИЕ НАДЕЖНОСТИ РАБОТЫ АЛМАЗОСОДЕРЖАЩИХ ИНСТРУМЕНТОВ, ПОЛУЧЕННЫХ ЛАЗЕРНЫМ ТЕРМОДЕФОРМАЦИОННЫМ СПЕКАНИЕМ, ПРИ ОБРАБОТКЕ АРМИРОВАНЫХ УГЛЕПЛАСТИКОВ}

\section{А. Ф. Саленко, В. Т. Щетинин, В. И. Глухова, Е. Е. Лашко}

Кременчугский национальный университет имени Михаила Остроградского

ул. Первомайская, 20, г. Кременчуг, 39600, Украина. E-mail: Salenko2006@ukr.net

Л. Ф. Головко, А. А. Саленко

Национальный технический университет Украины «Киевский политехнический университет

имени Игоря Сикорского»

просп. Победы, 37, г. Киев, 03056, Украина.

Мохамед Р. Ф. Будар

просп. Университетский, 8, г. Кропивницкий, 25006, Украина.

Рассматриваются вопросы обеспечения надежности работы алмазосодержащего инструмента, получаемого лазерным термодеформационным спеканием. Такой инструмент может использоваться для обработки углепластиков, углерод-углеродных материалов. При этом низкая обрабатываемость, повышенные температуры в зоне резания и ряд механико-химических явлений ведет к потере режущей способности инструмента. Предложенные вероятностные модели наступления параметрического отказа работы алмазосодержащего инструмента, показана его деградация в процессе эксплуатации. Показано, что лазерное термодеформационное спекание обеспечивает большую прочность зерна в связке, обеспечивает его больший вылет с поверхности, что позволяет улучшить условия работы инструмента. Приведены основы технологии лазерного спекания, предложен новый дозирующее устройство кольцевого типа для ввода алмазов. Также сделан вывод, что лазерное спекание позволяет более эффективно очищать и регенерировать алмазосодержащих слой инструмента.

Ключевые слова: углепластик, алмазосодержащих инструмент, лазерно-деформационное спекание.

АКТУАЛЬНІСТЬ РОБОТИ. Сучасне машинобудування характеризується різким зростанням обсягів використання композиційних матеріалів на основі скляних і вуглецевих волокон. Одним із факторів, що обмежує використання таких матеріалів на практиці, є їх важко оброблюваність, обумовлена структурою матеріалу та його компонентами. Так, зазвичай для фінішного формоутворення використовуються абразивний інструмент, переважно алмазовмісний $[1,2]$.

Характерною особливістю процесу розрізання вуглепластиків абразивним кругом $\epsilon$ ї інтенсивне зношування, яке полягає в випаданні окремих зе- рен через сильний абразивний вплив наповнювача оброблюваного матеріалу. Крім того, круг особливо інтенсивно засалюється продуктами деструкції полімеру.

Інтенсивність засалювання падає при рясному охолоджуванні звичайною водою. Однак, використання охолодження при обробці вуглецьвуглецевих матеріалів неприпустимо: це істотно обмежує сферу застосування для розрізання абразивних кіл. У той же час досвід використання для розрізання пластиків алмазних відрізних кругів показує, що застосування алмазного інструменту в порівнянні з абразивним дає збільшення швидкості 
і продуктивності в 1,5-3 рази і стійкості в десятки разів при поліпшенні якості обробки. Крім того, алмазні відрізні круги дозволяють проводити різання без охолодження рідиною.

У процесі механічної обробки полімерних композиційних матеріалів (ПКМ) одношарові алмазноабразивні інструменти неминуче зношуються. Для правильного розуміння фізичної сутності явищ, що протікають при контактній взаємодії робочої поверхні інструменту з оброблюваним матеріалом, зокрема, встановлення оптимальних режимів різання $\mathrm{i}$ призначення критерію затуплення алмазовмісного шару інструменту, важливо знати закономірності розвитку зносу інструменту i його природу, які багато в чому визначають ефективність пошуку раціональних умов обробки.

До теперішнього часу як в Україні, так і в ближньому і далекому зарубіжжі публікації з питань комплексного вивчення закономірностей зносу алмазно-абразивного інструменту та його стійкості при алмазно-абразивної обробки ПКМ вкрай обмежені за кількістю і не виходять за рамки приватних досліджень. Аналіз робіт $[3,4]$, в яких розглядаються питання зносу і стійкості абразивного і алмазного інструменту при обробці ПКМ і інших матеріалів на основі синтетичних смол, показав, що, по-перше, першопричиною зносу інструменту $\epsilon$ механічний фактор. До сих пір частина дослідників [5] причину інтенсивного зносу ріжучих інструментів пояснюють абразивним впливом оброблюваного матеріалу на різальний інструмент, незалежно від того, містить він або не містить тверді частинки наповнювача, що дряпають інструментальний і абразивний матеріали. Зокрема, причиною зносу абразивних інструментів при шліфуванні ПКМ є: руйнування і випадання з зв'язки зерен абразиву, забивання межзеренного простору інструменту стружкою оброблюваного матеріалу і продуктами його деструкції [4]. Основною причиною прогресивного падіння зносостійкості абразивних інструментів $є$ зменшення обсягу межзеренного простору і збільшення температури в зоні контакту, що призводять до деструкції стружки з утворенням речовин, що володіють адгезійними властивостями, які заповнюють западини між зернами i прилипають на ріжучі кромки абразивних зерен.

Для виготовлення алмазних інструментів використовують в основному три види технологічних процесів: гальванічне закріплення алмазів; порошкова металургія (гаряче пресування і брикетування); вакуумна технологія (дифузійне зварювання алмазних зерен) [6], проте існують ще й альтернативні технологічні процеси, такі як пошарове лазерне спікання і надзвукове плазмове напилення алмазного покриття.

За результатами чисельних досліджень лазерне спікання є найбільш перспективним процесом.

Мета роботи - забезпечення надійного функціонування алмазовмісного інструменту за рахунок раціональних умов проведення лазерного термодеформаційного спікання.

МАТЕРІАЛ I РЕЗУЛЬТАТИ ДОСЛІДЖЕНЬ. Незважаючи на значно більший коефіцієнт теплопровідності у синтетичних алмазів в порівнянні зі звичайними абразивними матеріалами, в зоні різання виникають високі температури, що наближаються при несприятливих умовах обробки до $800 \ldots 1000$ К. Вони безсумнівно впливають на інтенсивність перебігу механохімічних явищ при контактній взаємодії інструменту з оброблюваним матеріалом, а отже, і на знос алмазовмісного шару інструменту.

У початковий період роботи алмазних інструментів на вершинах зерен утворюються майданчики зносу, які безперервно зростають і впливають на процес мікрорізання і руйнування зерен і зв'язки. Особливо активно ці явища проявляються при обробці важкооброблюваних матеріалів, до яких належать i вуглепластики. Викришування зерен зв'язки алмазного круга при обробці ПКМ показано на рис. 1.
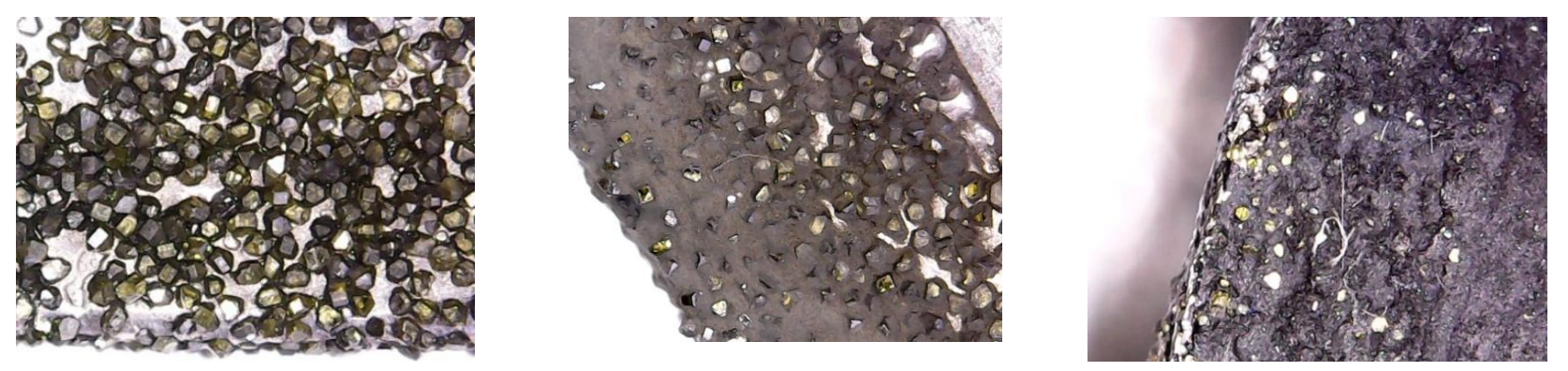

Рисунок 1 - Деградація алмазовмісного шару та викришування алмазних зерен при обробці вуглепластика

Залежно від умов шліфування розрізняють наступні основні види зносу (рис. 2): стирання, мікроруйнування, макроруйнування, виривання зерна із основи, хімічне руйнування, засалювання.
При лазерному спіканні вдається істотно скоротити динаміку зростання дефектів алмазовмісного шару і тим самим підвищити стійкість роботи інструменту та якість обробки вуглепластиків. 


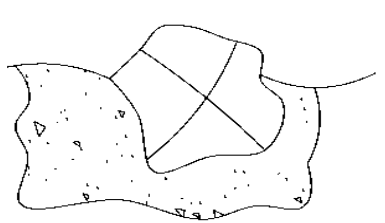

a)

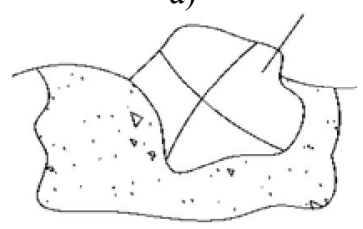

г)

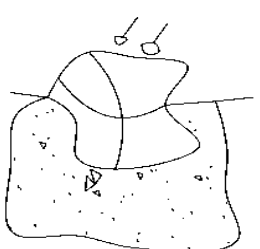

б)

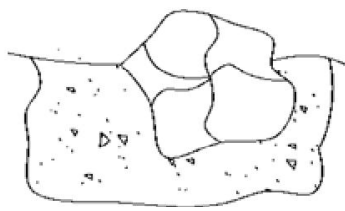

д)

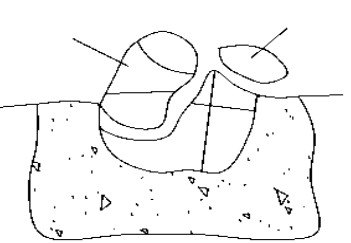

B)

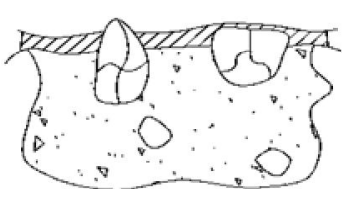

e)

Рисунок 2 - Основні види зносу алмазного інструменту: а) стирання ріжучих елементів шліфуються зерен 3 утворенням на них майданчиків з більшою або меншою шорсткістю; б) мікроруйнування зерен 3 відокремленням від них невеликих частинок; в) руйнування зерен з відокремленням від них невеликих частинок, порівнянних з розміром зерна; г) повне виривання зерен з зв'язки;

д) руйнування в результаті протікання хімічних реакцій в зоні контакту зерна з матеріалу, що оброблюється при високих температурах шліфування;

е) забивання проміжків між зернами стружкою і продуктами зносу

3 іншого боку, лазерне спікання дозволяе за рахунок високої швидкості безконтактного введення енергії в матеріал та ії прецизійного дозування здійснювати надшвидкісне нагрівання локальних областей матеріалів в широкому діапазоні температур, що дає можливість використовувати більш широкий спектр зв'язок, в тому числі і таких, які витримують температури нагрівання, що значно перевищують граничні, та забезпечують міцне поєднання між алмазовмісним шаром і сталевим корпусом інструменту, зумовлюючи підвищення його міцності. Висока

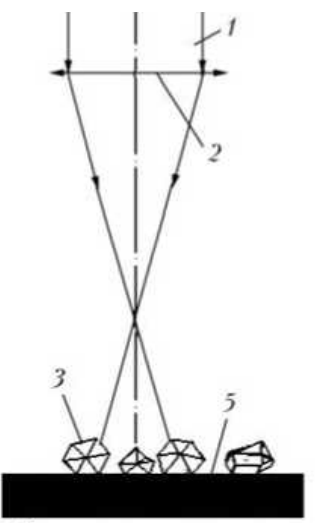

a)

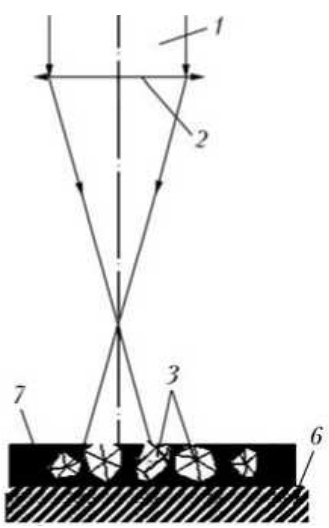

б) локальність процесу дозволяє пошарово формувати одно- або багаторядні алмазовмісні робочі елементи i таким чином отримувати інструменти практично будь-якої конфігурації, досить легко керувати концентрацією складових композитів, здійснювати термічне зміцнення зв'язки, отримувати структури, що мають високу дисперсність.

Схема традиційно виконуваного лазерного термодеформаційного спікання алмазовмісного щару подана на рис. 3.

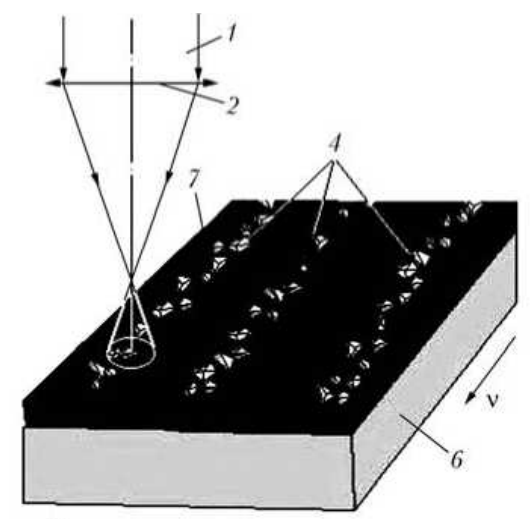

B)

Рисунок 3 - Схеми опромінення алмазів: а) - пряме опромінення; б), в) - розплавлення зв'язки з алмазами відповідно при різному часу експозиції і переміщаються щодо лазерного променю: 1 - лазерний промінь; 2 - лінза; 3, 4 - відповідно алмази занурені в зв'язку; 5, 6- відповідно графітова і сталева підкладка; 7 - зв'язка

Режими лазерної обробки мають забезпечувати швидке нагрівання зв'язки до температури плавлення у всьому обраному обсязі, плавлення поверхневого шару корпусу металевого інструменту і відсутність плавлення формоутворюючих поверхонь матриці. Саме тому задача забезпечення надійного функціонування інструменту вбачається у керуванні процесами локального нагрівання поверхні, яке не призводитиме до істотних деформацій основи інструменту.
Розглянемо постановку теплової задачі лазерного нагрівання поверхні алмазовмісного шару.

При дії лазеру тепло передається в інструмент та розподіляється між зернами алмазів і присадковим матеріалом. Зазвичай відбувається нагрівання частини основи інструменту, яка безпосередньо піддається лазерному впливу. Нерівномірність нагріву периферійної частини дискового інструменту радіусом $R_{1}$ можна встановити, записавши відповідні рів- 
няння для визначення напружені на зовнішній стороні поверхні диску:

$$
\left\{\begin{array}{l}
\sigma_{\tau}-\sigma_{\kappa}-r \frac{d \sigma_{r}}{d r}=0 \\
\varepsilon_{r}=\varepsilon_{\tau}+r \frac{d \varepsilon_{\tau}}{d r}
\end{array}\right.
$$

Виниклі на периферії напруження ведуть до появи радіальних та тангенціальних деформацій, причому останні визначаються як $\varepsilon_{\tau}=\frac{1}{E}\left(\sigma_{\tau}-\mu \sigma_{r}\right)+\alpha T$, що за умови недостатньо нагрітого центра диску викличе його викривлення убік на величину $\delta=\pi r \sqrt{\left(1+\varepsilon_{t}\right)^{2}-1}$. Зазначений прогин $\delta$ може компенсувати зусилля $F$, яке становитиме $F=\frac{16 \pi D}{R_{1}^{2}} \delta$.

Нагрів поверхні описує одномірне температурне поле для постановки задачі відносно периферії інструменту може бути отримане на основі розв'язку диференціального рівняння $q=q_{0} A=-\lambda_{T} \frac{\partial T}{\partial x}(0, t)$, $T(x, t)=\frac{2 q \sqrt{\alpha_{T} t}}{\lambda_{T}} i \Phi\left(\frac{x}{2 \sqrt{\alpha_{T} t}}\right)$.

Після припинення дії імпульсу теплового джерела тривалістю $\tau$ на поверхню, що нагрівається, відбувається іiі остигання за рахунок перерозподілу підведеного тепла. Одномірне температурне поле за умови, що оброблюване тіло являє собою напівнескінченний простір, може бути встановлене так:

$T(z, t)=\frac{2 A q_{0} \sqrt{\alpha_{T}}}{\lambda_{T}}\left[\sqrt{t} i \Phi\left(\frac{x}{2 \sqrt{\alpha_{T} t}}\right)-\sqrt{t-\tau} i \Phi\left(\frac{x}{2 \sqrt{\alpha_{T}(t-\tau)}}\right)\right]$

При цьому температура поверхні складе [7] $T_{0}(t)=\frac{2 q \sqrt{\alpha_{T} t}}{\lambda_{T}}$.

Оцінка характеристик теплового стану матеріалів під дією лазерного випромінювання може виконуватися на основі нелінійного однорідного рівняння в декартовій системі координат $\mathrm{X}(\mathrm{x}, \mathrm{y}, \mathrm{z}) \in \mathrm{R}^{3}$ :

$$
\begin{gathered}
c_{p i}(t) \rho_{i}(t) \frac{\partial t}{\partial \tau}=\frac{\partial}{\partial x}\left(\lambda_{i}(t) \frac{\partial t}{\partial x}\right)+ \\
+\frac{\partial}{\partial y}\left(\lambda_{i}(t) \frac{\partial t}{\partial y}\right)+\frac{\partial}{\partial z}\left(\lambda_{i}(t) \frac{\partial t}{\partial z}\right), \tau>0 ; i=1,3
\end{gathered}
$$

де $c_{p i}$ - теплоємність; $\rho_{i}$ - щільність матеріалу; $\lambda_{\mathrm{i}}$ коефіцієнт теплопровідності; $t$ - температура; $\tau$ час.

Для сполучного $(i=1)$ узагальнена постановка задачі Стефана має вигляд:

- для корпусу інструменту $(\mathrm{i}=2)$ :

$$
\lambda_{2}(t)=\lambda_{2} ;\left\lfloor c_{p}(t) \rho(t)\right\rfloor_{2}=c_{p 2} \rho_{p 2} ;
$$

- для матриці (i=3):

$$
\lambda_{3}(t)=\lambda_{3} ;\left[c_{p}(t) \rho(t)\right\rfloor_{3}=c_{p 3} \rho_{p 3},
$$

де $t_{m}$ - температура плавлення; $\Delta \mathrm{t}$ - інтервал згладжування; $\lambda_{\mathrm{s}}, \mathrm{c}_{\mathrm{ps}}, \rho_{\mathrm{s}}$ - теплопровідність, питома теплоємність та щільність сполучного у твердому стані; $\lambda_{\mathrm{m}}, \mathrm{c}_{\mathrm{pm}}, \rho_{\mathrm{m}}-$ теплопровідність, питома теплоємність та щільність розплаву сполучного; $L_{f}$ - непряма теплота фазового переходу 1-го роду сполучного; $\lambda_{2}, \mathrm{c}_{\mathrm{p} 2}, \rho_{2}-$ питома теплоємність і щільність матеріалу корпусу інструмента; $\lambda_{3}, \mathrm{c}_{\mathrm{p} 3}, \rho_{3}-$ теплопровідність, питома теплоємність та щільність матриці.

Початкові умови:

$$
\left.T(x, y, z)\right|_{\tau=0}=F(x, y, z)=t_{\text {medium }}
$$

де $t_{\text {medium }}$ - температура довколишнього середовища.

Граничні умови на зовнішніх поверхнях при $\tau>0$

$\left\{\Gamma_{1}:-\lambda \frac{\partial t}{\partial n}=q_{\mathrm{r}} ; \Gamma_{2}: \frac{\partial t}{\partial n}=0 ; \Gamma_{3}:-\lambda \frac{\partial t}{\partial n}=\alpha\left(t-t_{\text {medium }}\right) ;\right.$

Умови на границі контакту $\Gamma_{4}$ при $\tau>0$ :

$$
\left\{\begin{array}{l}
\left.t\right|_{\partial_{4}^{-}}=\left.t\right|_{\partial_{4}^{+}}, \\
-\left.\lambda_{-} \frac{\partial t}{\partial n}\right|_{\partial_{4}^{-}}=\lambda_{+} \frac{\partial T}{\left.\partial\right|_{\partial_{4}^{+}}}
\end{array}\right.
$$

$$
\left\{\begin{array}{l}
t<t_{m}-\frac{\Delta t}{2}, \lambda_{1}(t)=\lambda_{s} ;\left[c_{p}(t) \rho(t)\right]_{1}=c_{p s} \rho_{s} ; \\
t_{m}-\frac{\Delta t}{2} \leq t \leq t_{m}+\frac{\Delta t}{2}, \lambda_{1}(t)=\lambda_{s}+\frac{\lambda_{m}-\lambda_{s}}{\Delta t}\left(t-t_{m}+\frac{\Delta t}{2}\right) \\
{\left[c_{p}(t) \rho(t)\right]_{1}=c_{p s} \rho_{s}+\frac{c_{p m} \rho_{m}-c_{p s} \rho_{s}}{\Delta t}\left(t-t_{m}+\frac{\Delta t}{2}\right)+\frac{L_{f}}{\Delta t}} \\
t>t_{m}+\frac{\Delta t}{2}, \lambda_{1}(t)=\lambda_{m} ;\left[c_{p}(t) \rho(t)\right]_{1}=c_{p m} \rho_{m}
\end{array}\right.
$$

де $n$ - нормаль до поверхні; $q_{r}$ - щільність потужності; $\alpha$ - коефіцієнт тепловіддачі; $\Gamma_{1}-$ поверхня, що опромінюється , $\Gamma_{2}-$ поверхня осьової симетрії, $\Gamma_{3}-$ поверхні, що контактують із зовнішнім середовищем, $\Gamma_{4}$ - границя контакту сполучного і матриці.

Теплові режими визначатимуть пластичну деформацію поверхні, а також глибину занурення алмазів, міцність їх утримання матрицею. Виконуючи певне дозування, отримуємо змогу наносити алмазовмісний шар потрібної щільності та форми.

Таким чином, забезпечуючи відповідні температурні режими, витрату алмазів та умови нанесення їх на поверхню, формуються певні властивості ін- 
струменту, які у майбутньому забезпечують надійність його функціонування (рис. 4, [8]).

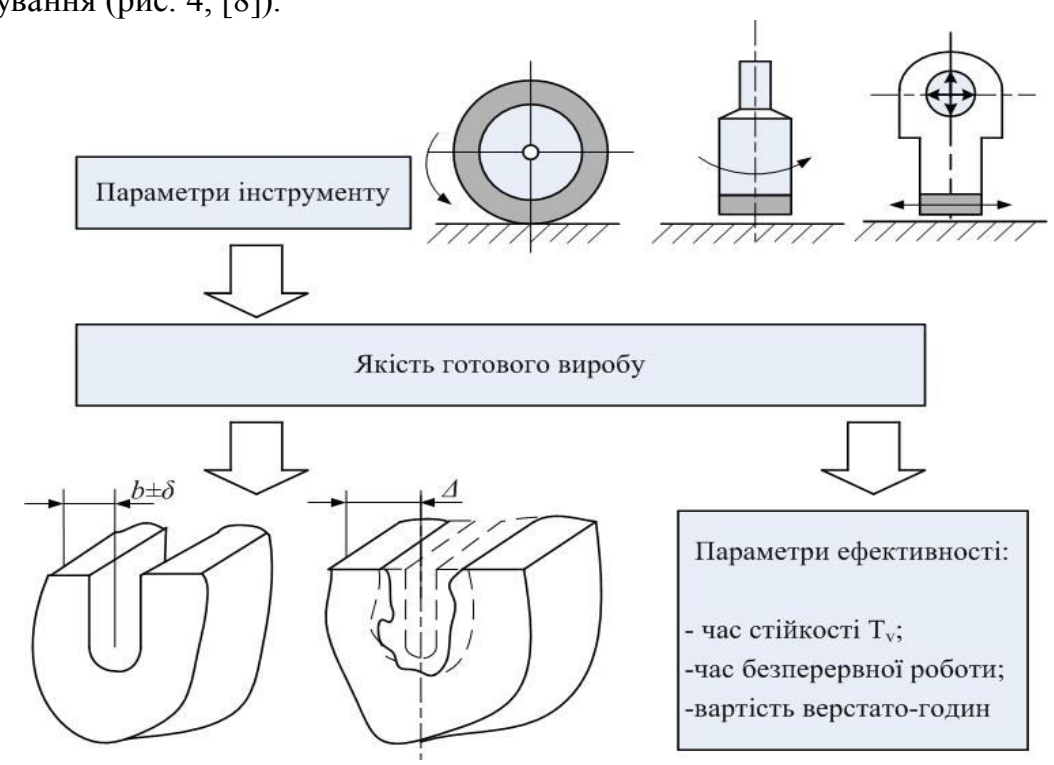

Рисунок 4 - Формування вихідних показників процесу різання ПКМ алмазовмісним інструментом

Нехай алмазовмісний інструмент має параметри (наприклад, різальну здатність), яка змінюється протягом часу. Як і будь-яка складна технічна система, обробна система, що поєднує інструмент, робочу машину, заготовку та носії зовнішнього впливу при функціонуванні має певний ансамбль реалізацій процесу, визначеного для подібних проміжків часу і обумовлених явищами системного та випадкового характеру.

Системні явища мають квазісталий, довготривалий характер, і можуть бути описані функціональними закономірностями, виявленими на основі статистичних спостережень за процесом або на основі теоретичного аналізу перетворень, що протікають при його реалізації.

Розглядаючи загальну схему формування відмови виробу (рис. 5), коли протікання різних процесів пошкодження приводить до зміни в часі вихідного параметра $X$, можна зазначити, що відмова виникне по досягненні параметром свого граничнодопустимого значення $X_{\max }$ через деякий випадковий проміжок часу роботи виробу.

При цьому основні етапи формування закону розподілу $f(t)$ наступні. Спочатку має місце розсіювання параметрів виробу $f(a)$ щодо свого математичного очікування $a_{6}$. Потім на погіршення параметрів виробу в процесі експлуатації позначаються повільноплинні процеси, наприклад, знос. У загальному випадку зміна параметра може початися через деякий проміжок часу $T_{6}$, який так само $є$ випадковою величиною i пов'язаний 3 накопиченням пошкоджень (наприклад, втомних) або 3 дією зовнішніх чинників.

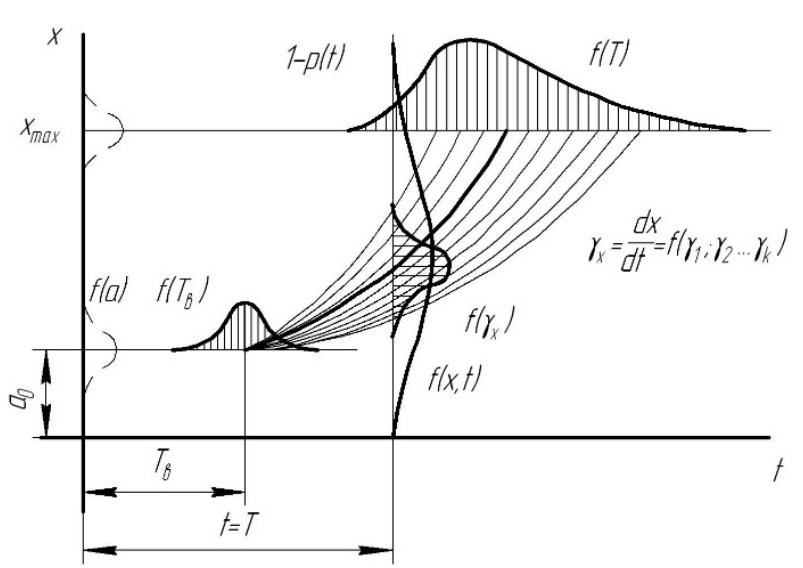

Рисунок 5 - Загальна схема формування відмов

Згідно [9] у разі, коли випадкові аргументи $a$ i $\gamma$ розподілені за нормальним законом, параметр $X$ для кожного значення $t=T$ буде розподілений по тому ж закону з параметрами: математичне очікування $X_{c p} \mathrm{i}$ середнє квадратичне відхилення $\sigma_{x}$ становитимуть:

$$
X_{c p}=a_{0}+\gamma_{c p} T, \quad \sigma_{X}=\sqrt{\sigma_{a}^{2}+T^{2} \sigma_{\gamma}^{2}},
$$

де $a_{0}$ - математичне очікування; $\sigma_{a}-$ середньо квадратичне відхилення випадкового параметра $a$. Тоді ймовірність $P(T)$ визначиться:

$$
P(T)=0,5+\Phi\left[\frac{X_{\max }-a_{0}-\gamma_{c p} T}{\sqrt{\sigma_{a}^{2}+\sigma_{\gamma}^{2} T^{2}}}\right]
$$

Одночасний прояв поступових і раптових відмов характеризується тим, що значення $P(t)$ може бути обчислене по теоремі множення ймовірностей, так як безвідмовність роботи деталі за час $t$ полягає у виконанні двох умов: безвідмовності від зносу, обумовленого пошкодженнями $P_{u}(t)$ і безвідмовності 
від раптових виходів з ладу $P_{s}(t)$. При незалежності цих відмов:

$$
P(t)=P_{u}(t) P_{B}(t)
$$

і при відомих параметрах законів розподілу $\left(T_{c p} ; \sigma\right.$, $\lambda$,), ймовірність безвідмовної роботи становитиме.

$$
P(T)=\left[0,5+\Phi\left(\frac{X_{\max }-a_{0}-\gamma_{c p} T}{\sqrt{\sigma_{a}^{2}+\sigma_{\gamma}^{2} T^{2}}}\right)\right] \cdot e^{-\lambda T}
$$

За умови, що повільно плинні процеси підкоряються закону нормального розподілу, а раптові експоненціальному.

Відповідно до [8] математичне очікування випадкового процесу в перерізі для відомої щільності ймовірності при безкінечній кількості реалізацій визначається залежністю:

$$
\begin{gathered}
m_{x}(t)=M[x(t)]=\int_{-\infty}^{+\infty} x p(x) d x \\
m_{2 x}(t)=M\left[x^{2}(t)\right]=\int_{-\infty}^{+\infty} x^{2} p(x) d x \\
D_{x}(t)=\sigma_{x}^{2}(t)=M\left[\left(x(t)-m_{x}\right)^{2}\right] .
\end{gathered}
$$

Зазвичай у технічних системах $є$ елементи або підсистеми (ланки), надійність функціонування яких безпосередньо визначає надійність реалізації заданого процесу в цілому.

Такою ланкою у даному випадку є сам алмазовмісний інструмент, у даному випадку, гама інструментів. Тоді елементами, які піддаються явищам зношування i які безпосередньо визначають, наприклад, продуктивність різання $q_{p}$, $є$ алмазовмісний шар та корпус інструменту (для шару це умовна кількість частинок на площині різальної поверхні $k_{c}$ та характеристика чистоти різальної поверхні $\mu$; для корпусу - його геометричні параметри, наприклад, діаметр $\left.D_{k}\right)$. Процеси зношування для цих елементів протікають 3 різною інтенсивністю, відповідно, різними є періоди стійкості $T_{k}$ та $T_{D}$. Оскільки такі елементи $є$ досить коштовними, вони безпосередньо визначають собівартість обробки $[10,11]$. Доля собівартості $W$, яка залежить від зазначених елементів (швидкозношувальних), визначиться так:

$$
W=C_{D} \frac{t_{0}}{T_{D}}+C_{k} \frac{t_{0}}{T_{k}}=t_{0}\left(\frac{C_{D}}{T_{D}}+\frac{C_{k}}{T_{k}}\right),
$$

де $t_{0}$ - операційний час, що визначається швидкістю робочої подачі $s_{p}$ та довжини контуру $L_{k}$ при обробці однієї заготовки:

$$
t_{0}=\frac{L_{k}}{s_{p}} .
$$

Тепер доля собівартості, віднесена на 1 продукції, визначається:

$$
W=\frac{L_{k}}{s_{p}}\left(\frac{C_{D}}{T_{D}}+\frac{C_{k}}{T_{k}}\right) .
$$

У разі, коли виникне параметрична або функціональна відмова, заготовка, яка в цей час буде оброблятися, виявиться забракованою, тобто виробник отримає втрати, що дорівнюють вартості заготовки (як правило, виникаючий брак є невиправним) $C_{3}$.
Оскільки зазвичай стійкість інструменту перевищує час машинної обробки, ситуація виникнення браку настане тоді, колі після початку роботи елементів буде оброблена певна партія деталей $N$. Передувати виникненню браку можна, якщо зменшити цю кількість на одиницю, тобто обробити $(N-1)$ виріб. При цьому, критичного зношування елементу досягнуто не буде, а заміна елементу дозволить ще певний час працювати у докритичних межах. Отже, для виробника повинна виконуватися умова:

$$
W \cdot(N-1)<W \cdot N+C_{3}
$$

Меншу стійкість елементів приймемо за лімітуючу. Тоді остання умова у виразі часу набуде вигляду:

$$
T_{m}-\Delta t<T_{m}-\left(\frac{C_{3}}{W}+1\right) t_{0} .
$$

А після перетворення отримаємо вираз:

$$
\Delta t>\left(\frac{C_{3}}{W}+1\right) t_{0},
$$

де $W$ визначається за (4).

Таким чином, збільшення часу експлуатації різального інструменту можливе як за рахунок повного відновлення його різальних властивостей шляхом нанесення алмазовмісного шару, так і за рахунок часткового відновлення, при якому повної заміни не відбувається, а поліпшення різальних властивостей досягається наприклад, шляхом відповідного очищення. Однак міцність алмазовмісного шару має бути такою, при якій виконання операцій очищення не завдаватиме шкоди самому шару.

Задача оцінки надійності процесу обробки алмазовмісним інструментом може бути вирішена шляхом пошуку функціональної обумовленості вихідних показників прийнятими до уваги параметрами елементів самого інструменту (в першу чергу, $k_{c}$ або $D_{k}$ ), тобто:

$$
\Delta \bar{J}=f\left(\Delta k_{c}, \Delta D_{k}, \Delta \mu, \ldots, \Pi_{a}\right),
$$

де $J$ - матриця відхилень показників якості крайки та продуктивності різання, отримуваній при реалізації процесу.

Експериментальні дослідження виконувалися на універсальному лазерно-струминному комплексі ЛСК-400-5, оснащеному твердотільним лазером потужністю 0,5 кВт, з довжиною хвилі 1069 нм, 3 частотою слідування імпульсів 50-750 Гц (рис. 6).

Лазер має фокусуючи систему та систему транспортування променя у вигляді «летючої оптики», із засобами переривання променю, а також ряду допоміжних систем, за допомогою яких можлива реалізації струминно-лазерної, кріогенної та гідро абразивної обробки. Конструктивно робочий стіл комплексу ЛСК-400-5 виконаний нерухомим; переміщення здійснює струминна головка, встановлена на траверсі 3 можливістю вертикального переміщення по координаті $Z$, що переміщується уздовж координати $X$ по напрямним столу. Переміщення виконується двома синхронізованими приводами подач, по 
одному на кожній балці, з синхронізацією за кутом повороту валів приводних двигунів. Сама головка на додатковій каретці прямує напрямними траверси за координатою $Y$. Додатково на вихідній ланці кіне-

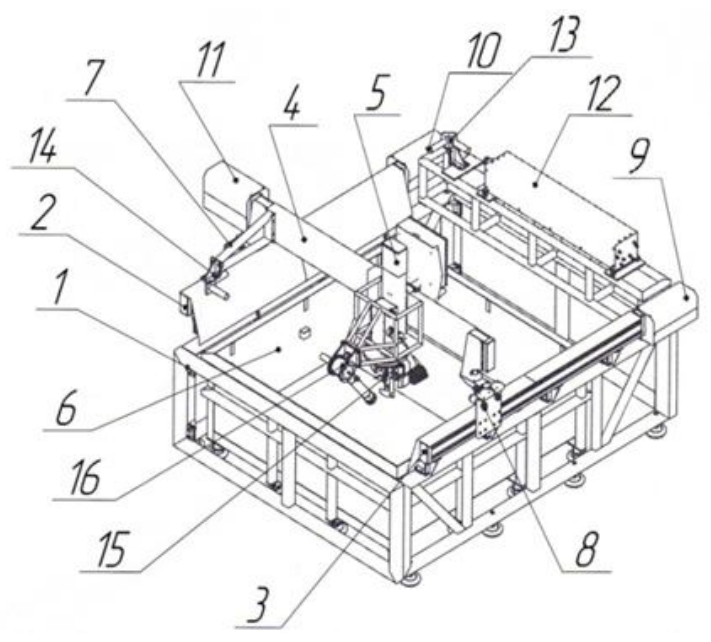

a) матичного ланцюга встановлено два обертових привода - довкола вертикальної осі $c$ та осі, розташованій у горизонтальній площині $a$.

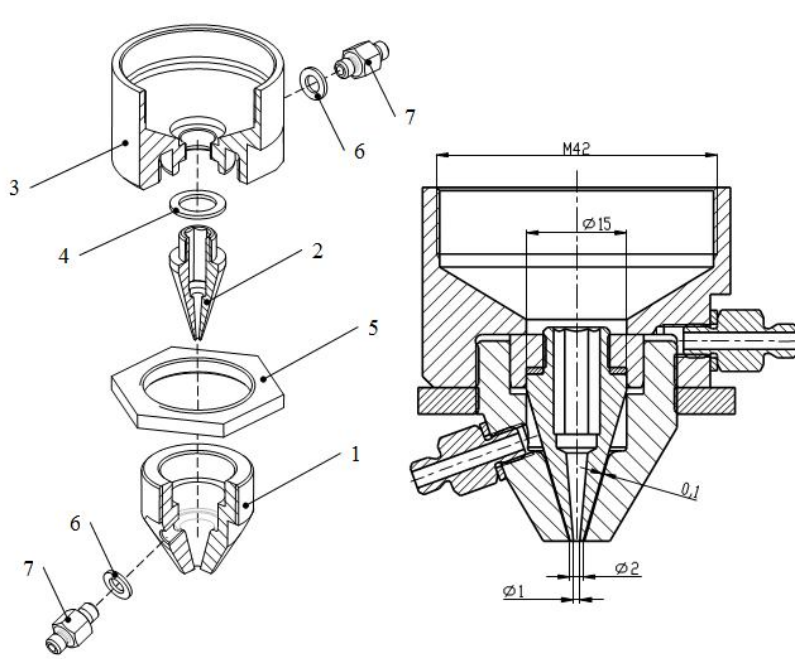

б)

Рисунок 6 - Елементи дослідницького обладнання ЛСК-400-5 (а) та використовувана кільцева головка(б):

1 - несуча система; 2, 3 - балки поздовжнього переміщення (Y-координати); 4 - балка поперечного переміщення (X-координати); 5 - балка вертикального переміщення (Z-координати); 6 - водоприймач; 7 - система «летючої оптики» твердотільного лазеру; 8 - каретка силового приводу; 9, 10, 11 - кожухи приводів; 12 - випромінювач лазеру; 13, 14, 16 - вузли повороту променю; 15 - обертова головка (з додатковими обертовими координатами В та С)

Приводи подач - електромеханічні, оснащені кульково-гвинтовою передачею, із кроковими двигунами типу ШД-5М. Для досягнення необхідної точності напрямні розвантажуються стисненим повітрям. Структурна схема комплексу відповідає формулі $3_{\text {ху }} \mathrm{OXYZacP}$.

Для введення алмазних частинок до робочої зони використовувався газово-дросельний пристрій транспортування, а сама робоча головка (рис. 6, б) виконана за коаксіальною схемою, тобто коли подавання частинок алмазів здійснюється газовим потоком крізь регульоване кільцеве сопло, в якому сфокусований промінь лазеру прямує уздовж центральної вісі. Додатково у зону наплавлення подається і присадковий порошковий матеріал (на основі дрібнодисперсного порошку $\mathrm{Ni}$ ).

Дослідження стану поверхні виконували на растровому електронному мікроскопі РЕМ-106I.

Параметри лазерного опромінення наведені в табл. 1.

Отримані результати оплавлення алмазних зерен порівнювали із передбачуваними розрахунковими значеннями, які відповідали наступним умовам:

- швидкість сканування при амплітуді 3,0 ..5,0 мм дозволяє вважати щільність потужності $10^{4} \mathrm{BT} / \mathrm{cm}^{2}$;

- зв'язник у нагрітому та розплавленому стані $(\mathrm{Ni}+0,5 \% \mathrm{~B}+10 \% \mathrm{Co})$, має теплофізичні характеристики як моноліту $\mathrm{Ni}$;

- поглинальна здатність матеріалу протягом часу взаємодії є постійною;

- наявність алмазів у композиті не враховувалася.
Таблиця 1 - Параметри лазерного опромінення

\begin{tabular}{|l|c|}
\hline \multicolumn{1}{|c|}{ Параметр } & Значення \\
\hline Потужність випромінювання, Вт & 500 \\
\hline Діаметр плями нагріву, мм & $0,4 \ldots 0,5$ \\
\hline Частота сканування, Гц & 150 \\
\hline Амплітуда сканування, мм & $4,0 \ldots 5,0$ \\
\hline Частота слідування імпульсів, Гц & 150 \\
\hline Час дії випромінювання, с & $1,5-3,0$ \\
\hline
\end{tabular}

Отримані результати дозволили визначити умови опромінення, глибину прогрівання та очікувану глибину оплавлення поверхні. За останнім параметром визначали очікувану глибину занурення алмазних зерен.

Після лазерної обробки алмази випробовували на статичну міцність за стандартною методикою. У разі, коли контрольовані параметри відповідали вимогам, інструмент піддавали робочим випробуванням. При цьому здійснювали різання вуглепластиків до моменту засалювання, встановлюючи час до настання так званої параметричної відмови, а потім піддавали очищенню, і випробування продовжували.

Зіставлення отриманих термогравіметруванням даних про температуру деструкції полімеру з експериментально отриманими даними про температуру в зоні різання при механічної обробки ПКМ дозволяє зробити важливий висновок. Висока температура зони різання, практично завжди перевищує термостійкість полімеру ПКМ, інтенсифікує протягом механохімічних процесів, які неминуче руйнують поверхневий шар, як обробленої поверхні полімерної 
композиції, так і алмазовмісний шар інструменту.

Нанесення алмазовмісного шару здійснювали на заготовки кругів діаметром 115 мм. Швидкість обертання кругу становила $0,5 \mathrm{c}^{-1}$, радіальне переміщення здійснювалося із перекриттям доріжок на величину 0,1-0,15 мм. Шар наносили на два круги, один використовували для випробувань різальних властивостей, інший - для мікроелектронного дослідження.

Після нанесення алмазовмісного шару готували препарат для мікроскопу РЕM-106I розмірами 10x10 мм.

Мікроелектронне дослідження поверхні інструменту, сформованої з використанням кільцевого сопла та присадкового припою 3 фракціями частинок 10/20 мкм, а також зерен алмазу фракцією 75/150 мкм показали, що регулювання витратою присадкових матеріалів, які прямують двома каналами, дозволяє отримувати достатньо гомогенні поверхневі алмазовмісні шари (рис. 7). Сполучник виявився повністю розплавленим, і вкривав поверхню основи інструменту шаром товщиною 25-40 мкм. На растрі спостерігається включення бруду, які, очевидно, потрапили у зону обробки внаслідок забруднень каналу підведення робочого газу.

Також установлено, що на дослідженій поверхні знаходиться і дефектне зерно. Оскільки однозначного висновку щодо псування зерна під час нанесення зробити не можна, потребує додаткового мікроелектронного аналізу стан зерен перед нанесенням.

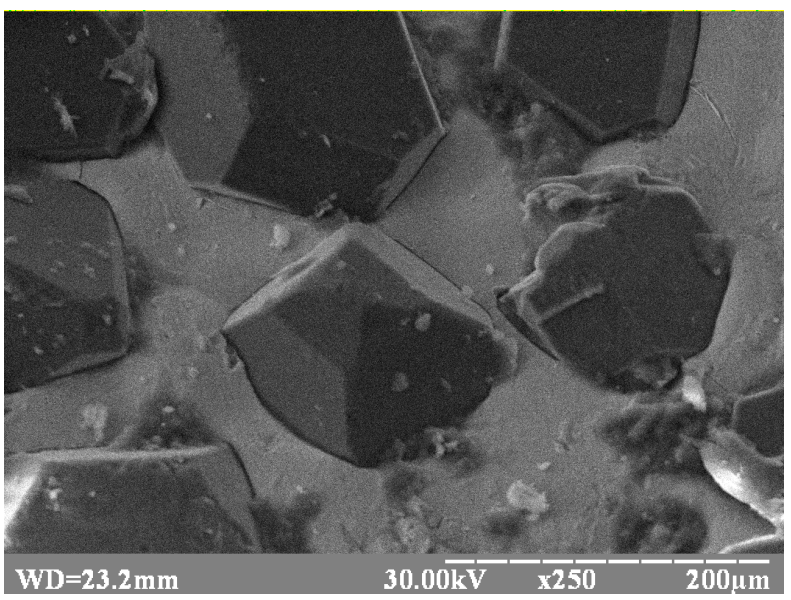

Рисунок 7 - Поверхневий шар інструменту із наявним дефектним зерном

Перевірка геометричних параметрів інструменту, які змінювалися внаслідок нагрівання лазером периферійної частини (із виникненням напружень відповідно до (1)) показала, що викривлення від початкової форми не перевищує 0,15 мм на зовнішньому боці кругу.

Випробування та порівняння різальних властивостей інструменту здійснювали при обробці ВВКМ та ПКМ

Різальні властивості кругів порівнювали, зіставляючи параметри процесу при використанні:

- нового кругу;

- гідроструминно очищеного після машинного часу, визначеного за (5), який для даних матеріалів і відповідної точності і вартості заготовки становив 30 хв роботи;

- нового аналогічного кругу серійного виробництва (тип 1A1RSS/C3 HIT Pro 125).

Здійснювали обробку вуглепластика ВКУ 25 та ВВКМ типу КИМФ. Перевіряли:

- якість поверхневого шару після обробки на предмет відсутності розшарувань та спучень, що характеризується відношенням товщини утворених дефектів до товщини оброблюваного матеріалу $R=\frac{\delta_{n}}{h}, h-$ глибина прорізаного пазу в матеріалі (або товщина розрізання листової заготовки);

- шорсткість поверхні $R a$;

- порівняння об’єму знімання матеріалів при зусиллі різання $18 \mathrm{H}$.

Зазначені параметри контролювали на основі зняття профілограм поверхневого шару та оптичного контролю стану поверхні після обробки (на прикладі обробки тестових заготовок, рис. 8, де наведено поверхню обробленого матеріалу ВКУ 25).

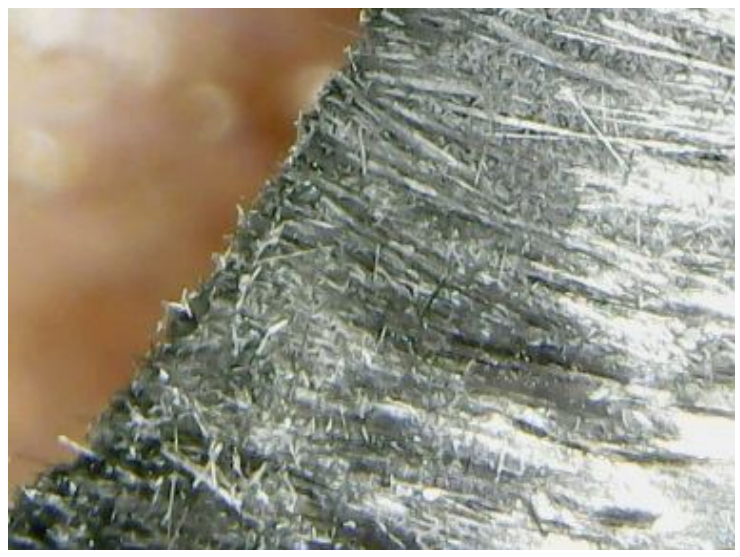

Рисунок 8 - Отримуваний пропил та розпушення торця вуглепластику при обробці інструментом із лазерним термодеформаційним спіканням

Із приведених на рис. 9 діаграм стає очевидним, що занурення інструменту (глибина $h$, мм) хоч і має певний вплив, не $\epsilon$ дієвим фактором, що обумовлює контрольовані величини шорсткості (за параметром $R_{a}$ ) та дефектності $(R)$. У той же час спостерігається істотна відмінність якості поверхні, обробленої традиційним (рис. 10, в) та пропонованим (рис. 9, а) інструментом. Так, якщо круг 1A1RSS/C3 HIT Pro 125 на матеріалі ВКУ 25 дозволяє отримувати різи задовільної якості із $R=0,045-0,055$ при $R_{a}=5 . .6$ мкм, то застосування запропонованого інструменту забезпечує $R=0,01-0,02$ при $R_{a}=2.5$ мкм. 

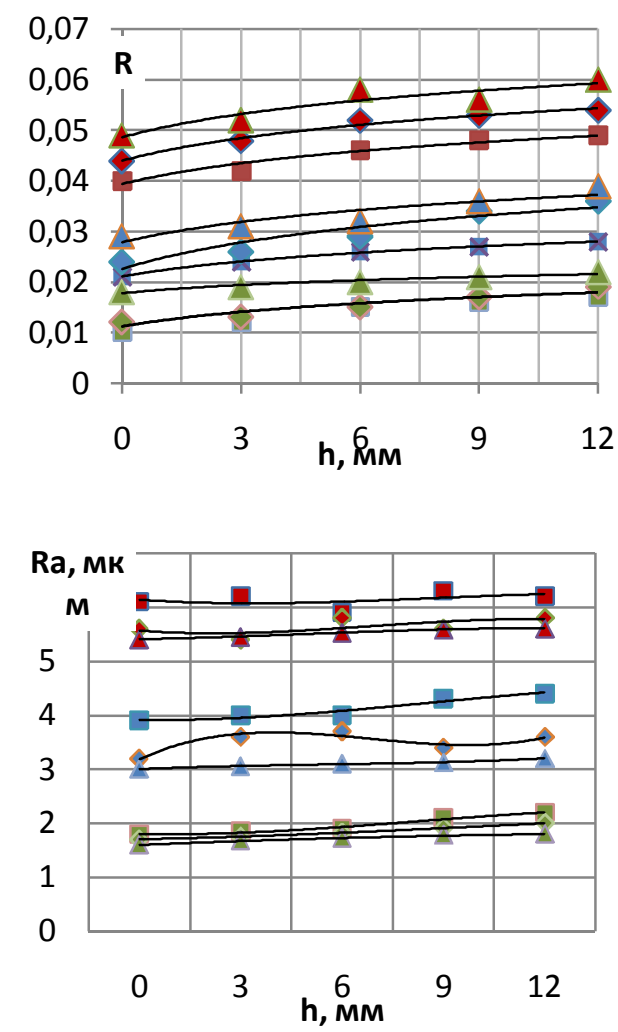

Рисунок 9 - Якість поверхневого шару при обробці пропонованим інструментом (a), очищеним (б) та традиційним (в)

Однак із часом зазначені показники погіршуються, і після відновлення засобами гідроструминного очищення отримати такі параметри вже досить складно (рис. 9 ,б): маємо відповідно $R=0,02-0,03$ при $R_{a}=3.2$ мкм.

Причиною $є$ те, що частина матеріалу після оброблення все ж таки залишається у поверхневому шарі (рис. 10); існують й інші окремі пошкодження алмазоносного шару.

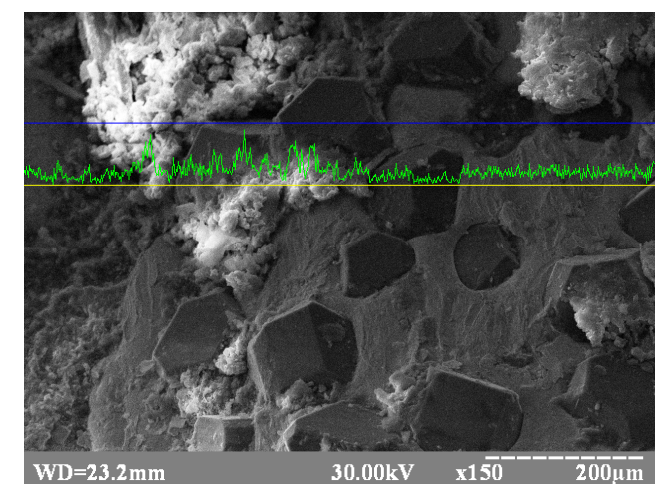

Рисунок 10 - Залишки продуктів мікрорізання між зернами алмазу

Порівнювали також і об'єм знімання матеріалом кругом запропонованої конструкції та відомих (у тому числі кругу $1 \mathrm{~A} 1 \mathrm{RSS} / \mathrm{C} 3$ HIT Pro 125 як кругу із високим вмістом алмазних частинок). Результати порівнянь приведені на рис. 11.

Стає очевидним, що відносно невисока щільність нанесення алмазних частинок на поверхню кругу (до

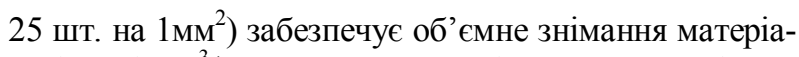
лу $1,5-2 \mathrm{~mm}^{3} / \mathrm{c}$, у той час як турбокруг може забезпечувати значно більшу продуктивність обробки. Дослідження проводили при навантаженні інструменту зусиллям $15 \mathrm{H}$ на маятниковій відрізній машині.

Отриманий результат дозволив зробити важливий висновок стосовно того, що для підвищення продуктивності процесу поверхня інструмента повинна мати певні визначені ділянки, які умовно можна називати кластерами. Такі кластери можуть відрізнятися щільністю алмазних зерен, товщиною їх викладання, профілем тощо. Це дозволить залучити функціонально-орієнтований підхід до створення нових алмазоносних шарів та отримати високоефективні абразивні поверхні, орієнтовані на використання конкретного матеріалу (зокрема, застосувати підхід [12]).

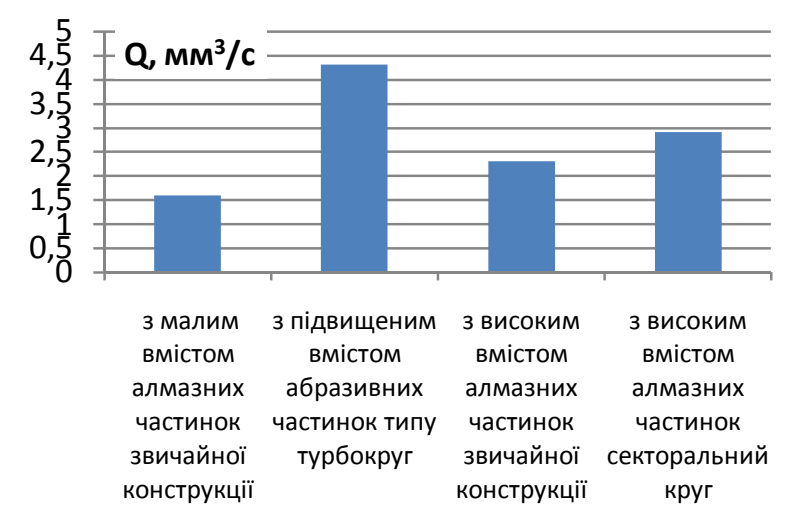

Рисунок 11 - Порівняння об'ємного знімання матеріалу кругу пропонованої конструкції (1), турбокругу (2), кругу 1A1RSS/C3 HIT Pro 125 (3) та секторального кругу (4)

Проведені дослідження виконувалися до повного руйнування поверхневого алмазовмісного шару, що дало змогу отримати певну статистичну вибірку для визначення параметрів моделі настання відмов за (3). Оскільки випробуванням піддавали фактично один зразок інструменту, достовірність результатів складає 95\%.

Якщо за параметр $X_{\max }$ прийняти продуктивність процесу (цей параметр є узагальнюючим і для рівнянь (4) та (5)), визначену при фіксованій робочій подачі або фіксованому зусиллю різання (у даному випадку $15 \mathrm{H}$ ), то параметричною відмовою можна вважати зниження продуктивності менше чим на $1 \mathrm{Mm}^{3} / \mathrm{c}$. Тоді $\mathrm{a}_{0}=0,27, \sigma_{\mathrm{a}}=0,045, \gamma=0,00037 \mathrm{Mm}^{3} / \mathrm{c}$, $\sigma_{\gamma}=0,000012$, а очікуваний потік відмов $\lambda=0,000025$.

ВИСНОВКИ. Проведений комплекс теоретикоекспериментальних досліджень, у тому числі, і випробувальних, дозволив зробити висновок щодо доцільності застосування технологій лазерного термодеформаційного спікання алмазовмісних шарів сучасного інструменту, що використовується для обробки вуглепластиків та вуглець-вуглецевих композицій типу КИМФ. 3 цією метою запропоновано 
використовувати спеціальний коаксіальноструминний пристрій із вільним вікном, який дозволяє вносити у зону нагріву поверхні лазерним випромінюванням присадкового порошкового матеріалу та алмазних зерен. Зазначений пристрій володіє широкими технологічними можливостями, і дозволяє застосовувати функціональний підхід для формування різних робочих профілів поверхні інструменту, тобто без переналагодження спеціального оснащення здійснювати зміну товщини нанесеного шару, зміну щільності нанесених частинок тощо. Кластери алмазоносного шару можуть бути орієнтованими на роботу із певними вуглецевими матеріалами (різними видами пластику, карбонкарбоновими сполуками).

Застосування запропонованої теплової задачі дозволило визначити умови формування алмазовмісного шару залежно від витрати робочого газу із присадковим порошковим матеріалом, а також із алмазними зернами. Показано, що пропонований підхід до лазерного термодеформаційного спікання дозволяє отримувати більш прогресивний різальний інструмент, підвищити його стійкість та відновлюваність при обробці пластиків.

\section{ЛІТЕРАТУРА}

1. M. Rahman, S. Ramakrishna, J.R.S. Prakash, D.C.G. Tan. Machinability study of carbon fiber reinforced composite, Journal of Materials Processing Technology No. 89-90, 1999, pp. 292-297.

2. Kaneeda T., Masayuki T., CFRP cutting mechanism ( $1^{\text {st }}$ report): surface generation mechanism in very low speed. Journal of Japan Society of precision engineering, 1989, pp. 1456-1461.

3. Wang D., Arola D., Ramulu M. Orthogonal cutting mechanism of graphite/epoxy composite.
International Journal of Machine tools and manufacture. No. 35, 1995, pp. 1623-1638.

4. Singh I., Dvivedi A. Joining of natural fiber reinforced thermoplastic composites. Biomass-Based Biocomposites, Smithers Rapra Publisher, 2013, pp. 145-164.

5. Nunes J., Silva J., Novo P., Marques A. Technological development to produce low cost thermoplastics reinforced composites. $7^{\text {th }}$ European Conf. Of Advanced materials and processes. 2001.

6. Fang N. Slip-Line Modeling of Machining with a Rounded-Edge Tool. Part I: New Model and Theory. Journal of the Mechanicsand Physics of Solids. No. 51, 2003, pp. 715-742.

7. Senthilkumar V. Laser cutting process, International journal of Darshan Institute on Engineering Research \& Emerging Technologies. Vol. 3, No. 1, 2014.

8. A. F. Salenko, V. T. Shchetinin, A. N. Fedotiev, V. A. Dudyuk, S. A. Klimenko Methods of cutting for workpieces of hardmetal and cBN-based polycrystalline superhard material, Journal of Superhard Materials, No. 37 (4), pp. 271-281.

9. Дудюк В. О., Мельничук П. П. Особливості моделі надійності гідроабарзивного різання для сучасних композиційних матеріалів. Вісник Кременчуцъького національного університету імені Михайла Остроградського, м. Кременчук. Вип. №6, 2016. C. 64-84.

10. O. Salenko, O. Mana and et. Appling of functional approach to obtaining blind and through cuts in the Workpieces of Hard and Superhard Sintered materials by Jet Methods, 14 th International conference Research and development in Mechanical Industry, 2014, pp. 151-160.

\section{PROVIDING THE RELIABILITY OF THE WORK OF THE DIAMONDS TOOL PRODUCED BY LASER THERMODEFORMATION SUCTION AT THE PROCESSING OF ARMED CARBONS}

O. Salenko, V. Shchetynin, V. Glukhova, Ye. Lashko

Kremenchuk Mykhailo Ostrohradskiy National University

vul. Pershotravneva, 20, Kremenchuk,39600, Ukraine. E-mail: salenko2006@ukr.net

L. Golovko, A. Salenko

National Technical University of Ukraine "Kyiv Polytechnic Institute named after Igor Sikorsky"

vul. Peremohy, 37, Solomensky District, Kyiv, 03056, Ukraine

\section{Mohamed R. F. Budar}

vul. Universitetskyi, 8, Kropivnitsky, 25006, Ukraine

Purpose. The use of modern composite materials, in particular carbon, requires finishing treatment for the purpose of forming. Such processing is usually carried out by a diamond tool. The application of a layer of diamonds in the latter is assumed by galvanosteyge. However, when processing these plastics, diamond grains are stained and processing becomes impossible. Methodology. The possibility of using laser thermal deformation sintering of the surface layer with diamond grains to improve the reliability of the tool is considered. To assess the temperature fields on the surface of the instrument base, the thermal problem of laser action on the surface of powdered filler and diamond grains is considered. The laws of melting of the adhesive layer are established, as well as the modes under which a given height of grain is reached and high strength of its retention in a bundle is ensured. The models of failures are given, the conditions for stopping the operation of the tool are given. Results The expediency of application of technologies of laser thermodeformation sintering of diamond-bearing layers of the modern tool used for processing carbon-plastics and carboncarbon compositions of the KIMF type is used. Appropriate models have been developed to determine the rational modes of dying. It is shown that the proposed approach to laser thermoformation sintering allows us to obtain a progressive cutting tool, to increase its durability and restorability when processing plastics.Originality. The application of the proposed thermal problem allowed to determine the conditions for the formation of the diamond-bearing layer, depending on the flow of the working gas with the additive powder material, as well as with the diamond grains. Practical value. It is proposed to use a special coaxial jet device with a free window, which allows the surface to be heated into 
the zone of surface heating by laser radiation of the additive powder material and diamond grains. This device has wide technological capabilities and allows us to apply a functional approach to form various working profiles of the surface of the tool, that is, without changing the special equipment: to change the thickness of the applied layer, to change the density of the applied particles, etc. Clusters of the diamond-bearing layer can be oriented to work with certain carbon materials (various types of plastic, carbon-carbon compounds).

Key words: carbon fiber plaster, diamond tool, laser-deformation sintering.

\section{REFERENCES}

1. Rahman, M., Ramakrishna, S., Prakash, J. R. S., Tan, D. C. G. (2009), Machinability study of carbon fiber reinforced composite, Journal of Materials Processing Technology, no. 89-90, pp 292-297.

2. Kaneeda, T., Masayuki, T. (1989), CFRP cutting mechanism $\left(1^{\text {st }}\right.$ report): surface generation mechanism in very low speed, Journal of Japan Society of precision engineering, pp. 1456-1461.

3. Wang, D., Arola, D., Ramulu, M. (1995), Orthogonal cutting mechanism of graphite/epoxy composite, International Journal of Machine tools and manufacture, no.35, pp. 1623-1638

4. Singh, I., Dvivedi, A. (2013), Joining of natural fiber reinforced thermoplastic composites, BiomassBased Biocomposites, Smithers Rapra Publisher, pp. $145-164$.

5. Nunes, J., Silva, J., Novo, P., Marques, A. (2001), Technological development to produce low cost thermoplastics reinforced composites, $7^{\text {th }}$ European Conf. Of Advanced materials and processes.

6. Fang, N. (2003), Slip-Line Modeling of Machining with a Rounded-Edge Tool. Part I: New Model and
Theory, Journal of the Mechanics and Physics of Solids, no. 51, pp. 715-742.

7. Senthilkumar, V. (2014), Laser cutting process, International journal of Darshan Institute on Engineering Research \& Emerging Technologies vol. 3, no. 1.

8. Salenko, A. F., Shchetinin, V. T., Fedotiev, A. N., Dudyuk, V. A., Klimenko, S. A. (2015), Methods of cutting for workpieces of hardmetal and cBN-based polycrystalline superhard material, Journal of Superhard Materials, No.37 (4), pp. 271-281.

9. Dudyuk, V., Melnichuk, P. (2016), Features of model of reliability of hydroabrasive cutting for modern composite materials [Osoblyvosti modeli nadiynosti hidroabarzyvnoho rizannya dlya suchasnykh kompozytsiynykh materialiv], Transactions of Kremenchuk Mykhailo Ostrohradskyi National Universitym. Iss. 6, pp. 64-84.

10. Salenko, O., Mana, O. and et. (2014), Appling of functional approach to obtaining blind and through cuts in the Workpieces of Hard and Superhard Sintered materials by Jet Methods, 14 th International conference Research and development in Mechanical Industry, pp. 151-160.

Стаття надійшла 16.05.2019. 